\title{
The Development of Chorus Motivation Scale (CMS) for Prospective Music Teacher
}

\author{
Ilhan Ozgul $^{1} \&$ Nalan Yigit $^{2}$ \\ ${ }^{1}$ Faculty of Education, Kastamonu University, Kastamonu, Turkey \\ ${ }^{2}$ State Conservatory, Ankara University, Ankara, Turkey \\ Correspondence: Ilhan Ozgul, Faculty of Education, Department of Fine Arts Education, Kastamonu University, \\ Kastamonu, Turkey. Tel: 90-366-280-3342. E-mail: ilhanozgul@kastamonu.edu.tr
}

Received: May 23, 2017

doi:10.5539/jel.v6n3p323
Accepted: June 7, 2017

Online Published: June 11, 2017

URL: http://doi.org/10.5539/jel.v6n3p323

\begin{abstract}
The purpose of this study was to develop a Chorus Motivation Scale (CMS) that is tested in terms of reliability and construct validity by determining the student perceptions of effective motivation strategies in Chorus training in Turkish Music Teacher Training Model. In order to develop a Chorus Motivation Scale, Questionnaire-Effective Motivation Strategies in Chorus Training was applied to second-year, third-year, and fourth-year students who study at Music Teacher Training departments of nine different state universities from seven geographical regions in Turkey $(\mathrm{N}=794)$. Exploratory Factor Analysis (EFA) and Confirmatory Factor Analysis (CFA) were conducted in accordance with new/initial scale development procedures. Analysis of the data reveals a good structure model comprising reliable factors. Confirmatory factor analyses indicated that a model including factors representing the dimensions Leadership, director/student attention, achievement and anxiety was the best fit. The four-factor model yielded RMSEA and SRMR values $(\leq .05)$ demonstrating an excellent fit and CFI value with an adequate fit to the data. Cronbach's alpha and initial-final reliability results indicated good to excellent consistency across all CMS subscales, with coefficients ranging from .64 to .90 .
\end{abstract}

Keywords: Chorus Training, motivation, Chorus Motivation Scale, prospective music teacher

\section{Introduction}

Motivation is one of the leading problems educators from all levels of education have to deal with. Motivation gains importance throughout university education. Because university education is the final step of formal education process for students before getting a job. Educators must acquire precise knowledge about some concepts, theories, principles, and practices related to motivation. Upon taking educational decisions, when they become obliged to overcome some issues that contain concerns about motivation, they have to know which of this information they will trust and how to do it and distinguish between right or wrong motivational beliefs (Ames, 1990; Tosi, 1991; Svinicki, 2002; Renwick \& McPherson, 2002; Pintrich \& Schunk, 2002; Dowsona \& McInerney, 2003; Brophy, 2004; Tileston, 2004; Tarr, 2005; Brewer \& Burgess, 2005; Glynn \& Koballa, 2006; Bowman, 2007; Boekaerts, 2010; Lai, 2011; Hruska, 2011; Lee \& Reeve, 2012).

Studies on motivation in chorus training usually focus on three approaches. (a) one approach contains observation of expert directors during choral rehearsals and their approaches regarding motivation, (b) one focuses on rehearsal organizations as an instrument of stimulating student motivation, (c) one investigates chorus directors' behaviors and their communication skills (Stamer, 1995; Guo, 2001; Gumm, 2004; Grimland, 2005; Amoto \& Neto, 2007, 2008; Gözen, 2010; Öztürk, 2010; Riggs, 2011; Amoto, 2011; Ganschow, 2012). Although these research studies undoubtedly make a significant contribution to the field of motivation for choral rehearsals, such approaches regarding motivation may fail to contribute to stimulation/motivation of all students to learn. These studies investigated or examined chorus directors' behaviors rather than directly taking account of student needs. In this sense, approaches/strategies that contribute to motivation to learn about choral classes should be determined by asking prospective music teachers. 


\subsection{Theoretical Framework}

\subsubsection{Chorus Training}

The overall objective of chorus training is to obtain a single voice, efficient and capable of coalescence, incorporating features of the mother tongue spoken in that country, which is suitable for singing along in a community by individual and group work applied to that community. Participation in arts activities is known to primarily bring self-confidence and create free people (Egüz, 1981). A Turkish study aimed to evaluate the educational, social and cultural improvements in individuals taking part in several amateur choirs in Turkey. From the findings it was concluded that choir members behave more sensitively, more consciously and more selectively (Öztop, 2007). Chorus training starts with formation of choirs and covers subject areas, including choir layout, voice training, voice health, choral culture and discipline. Choir conducting can not be discussed as a single discipline distinct from choir training. Because conducting a choir while training it and training it to be able to conduct it are nested processes and take place in the same time period. In one sense, choir conducting is using all communication tools required to develop musical style and formation, interpretation skills, general knowledge of a choir (Çevik, 1997).

From the viewpoint of an untutored bystander, the choral director's art constitutes a director in place before a group of singers, baton in hand (or not), leading the coordinated singing effort of the chorus. End of story? Clearly not. The director's art is far more complex. It requires skills in the intellectual, physical, and social arenas. It entails expertise in matters musical, historical, linguistic, and vocal. Further knowledge in the areas of leadership, performance psychology, and the mental processes that enhance rehearsal and performance add immeasurably to the director's success. To inform and enrich their interpretive choices, choral directors draw upon their knowledge of music history—periods, styles, performance practice — and their training in music theory: how elements of pitch, rhythm, harmony, and form create meaningful structure. Beyond these, choral music embodies the added element of language. Choral directors are sensitive to the literary intent of text and to the subtext of the music. Recognizing and understanding literary devices-homily, irony, metaphor-deepens the artistic level of interpretation (Emmons \& Chase, 2006).

Attributes of an effective choral conductor; Philosophical and pedagogical awareness: knowledge and understanding of how the voice works, knowledge of choral repertoire, awareness of the stages of children's and adolescents' vocal development, awareness of the social, psychological and physical effects of choral participation on the individual. Musical and technical skills: good gestural vocabulary, good posture, good aural and error detector skills. Interpersonal and leadership skills: non-verbal communication (through vocal modelling and eye contact), encouragement/motivation, quality feedback, clear communication goals, enthusiasm, ability to work well with people, effective rehearsal pacing and planning (Durrant, 2009; Varvarigou \& Durrant, 2011).

General principles of musical leadership are classified in the following way. The leader presents a vision to the followers, technical expertise -musical, vocal, psychological-, is an able teacher and an articulate communicator, motivates his or her followers, a competent time manager, knows how to run a productive rehearsal, puts personal ambitions and self-interest to the side, channeling them toward the interests of the group, is accessible to his or her followers, is patient, but resolute, is trustworthy (Emmons \& Chase, 2006).

Characteristics of an efficient choral music educator are classified under three dimensions, including "musical, teaching and personal behaviors". Essential musical skills might include knowledge of how the voice develops in middle school and high school singers, ability to play vocal parts on the piano, conducting skills, ability to hear errors in individual vocal parts when the whole choir is singing, memorization of the choral score, knowledge of choral music repertory that is effective for secondary school students, how to achieve a beautiful choral tone and excellent diction, and knowledge of music theory and history. Essential teaching characteristics might include: commitment to musical excellence, commitment to student growth, knowledge of effective rehearsal strategies, organization, good classroom management and discipline skills, the ability to engage and work with people (students, parents, other teachers, etc.), and experience directing a choir. The most essential personal skill is the desire to be a choral music teacher. If you love choral music and the idea of sharing that enthusiasm with your students, you have the right motivation for developing the personal skills required to teach. Any commitment requires hard work, but the desire to do what you love makes it a labor of love (Madura Ward-Steinman, 2010).

According to Varvarigou and Durrant (2011), an effective choral conductor educator should ideally adopt a pedagogical approach that enables learners to grow within their learning context. Some suggested attributes for effective teaching applied from a wider research perspective (Jennings, 1994) are related to (i) management of (choral) material, (ii) the tutor's expectations/aspirations, (iii) the tutor's perceptions of the subject matter, (iv) 
planning and preparation, (v) monitoring the learners' development and (vi) evaluation through feedback. Stegman (2001) classifies choral music teachers' perceptions of instructional strategies and styles under two sub-headings, including teacher-centered and technical approaches and learning opportunities and affective approaches, and notes that today's changing education paradigms are interested in affective approaches. De Masi (2003), in particular, refers to the responsibility of the chorus director in human resource management. The chorus director is more a person ensuring organization of sound production than "a technical expert" on choral music and he also performs a function of conducting a group of people organized under the leadership of the chorus director. In this sense, maintaining group relations "in a positive scenario" can manifest increasing power of group commitment of a reliable chorus director.

\subsection{Motivation}

According to Maslow (1954), motivation is anything that provides insistence, concentration and management for a behavior. Brophy (2004) defines motivation a condition that is associated with the students' reasons for doing something, their learning activities, and in particular them being volunteers to make effort during lessons. It can be defined as "an internal condition related to the fact that the students maintain, manage and advance their behaviors" (Robenstine, 1997; Pintrich \& Schunk, 2002; Jensen, 2005; Glynn \& Koballa, 2006). Motivation involves a constellation of beliefs, perceptions, values, interests, and actions that are all closely related (Lai, 2011).

Various approaches to motivation can focus on cognitive behaviors (such as monitoring and strategy use), non-cognitive aspects (such as perceptions, beliefs, and attitudes), or both. For example, Gottfried (1990) defines academic motivation as enjoyment of school learning characterized by a mastery orientation; curiosity; persistence; task-endogeny; and the learning of challenging, difficult, and novel tasks. On the other hand, Turner (1995) considers motivation to be synonymous with cognitive engagement, which he defines as "voluntary uses of high-level self-regulated learning strategies", such as paying attention, connection, planning, and monitoring (Lai, 2011).

Motivation can not be observed directly; inferences can be made from behaviors. These behaviors aim at the organization's mission or targets are identified by the word performance. So, performance, which is used as a synonym for behavior, is a concept more common than motivation. Logically, liking a particular activity is believed to produce high performance, whereas it has an indirect effect (Pintrich \& Schunk, 2002; Emmons \& Chase, 2006). Experienced teachers know the basic difference between inspiration and motivation in the classroom (Secretan, 2005). While motivation is the fact that an individual focus himself/herself on something, inspiration is the fact that another individual makes one to focus on something. Characteristically, providing motivation is an effect or a strategic approach carried out by a teacher for his/her student. Source of inspiration is a result of guidance relationship with students, helping them, and a result of trust. Inspiration is an extraordinary approach and it is difficult for every educator to achieve it. Extraordinary teachers guide students by inspiring them to discover intersection points of their talents and passions (Bowman, 2007, 2011).

\subsection{Motivation Variables}

Madeline Hunter identified six variables that teachers can use to stimulate student motivation: "level of concern", "feeling tone", "interest", "success", "knowledge of results", and "relation of activity to reward". Stamer (1999) studied the behaviors that a choir conductor should adopt to create an atmosphere in the choir rehearsal that motivates the choristers to learn, using six variables regarding to the student's motivation developed by Hunter. The author highlighted also that the specificity of each group originated the application of different motivational strategies; that is to say, the strategies should be in accordance with the choristers/students age group, the objectives intended by them when they participate of the choir and the group goals. For Stamer (1999, p. 26): The most effective motivational technique that the musical chorals educators can use is to pay attention to its students' personal and musical development ("attention conductor/student").

Student/teacher attention, one of motivation variables, was discussed in several studies including examples of classroom environment. Examinations of classroom environment (Frazier, 1985; Mergendoller \& Packer, 1985; Ray, 1992; Stamer, 1995) have indicated that student motivation was enhanced when the teacher was seen as enthusiastic, nurturing, and interested in student progress. There are three important points which will pave the way for students' motivation so that teachers succeed in the classroom. The first two items explain common aspects of learning communities, while the third refers to the aspect of learning. (a) Teachers should make themselves and the class/course environment engaging/appealing for students, (b) focus students' attention on individual and collaborative learning targets and help them achieve these targets, and (c) pay attention to teaching valuable things/contents which students will appreciate (Brophy, 2004). 
Educators are often used to self-evaluation in three areas: education/teaching, relationships, and management. Education includes teaching skills and competencies. Relationships are related to attitudes of educators toward students. Management is related to classroom organization and planning. These three categories represent the main areas which an educator working in a university should keep under control (Brewer \& Burgess, 2005; Miksza et al., 2010). Every teacher certain innate personal characteristics in addition to learned behaviors and characteristics. Effective teachers help their students learn, organize and support their learning, they are supportive, reassuring, democratic, concerned about students' happiness, knowledgeable about the subjects they will teach, happy to be with their students, and enthusiastic about their job. Music teachers should also have self-efficacy, positive verbal and non-verbal communication skills and strong leadership skills (Özgül, 2009; Stelee, 2010).

Feedback, one of motivation variables, is defined as the information provided by an agent based on one's performance or terms of understanding (teachers, peers, books, family, experience). It typically occurs after a teaching/instruction given seeks to make someone gain knowledge and skills or a certain behavior (Hattie \& Timperley, 2007; Zhukov, 2008). Feedback used in educational content is important in acquiring knowledge, ideas and behaviors on developing students' learning (Shute, 2008, p. 153). Immediate and specific feedback given during studies helps students know what they need to be successful. If students know that they are doing the activity correctly, they are likely to focus more on the learning process (Tileston, 2004). Specific feedback received from the teacher responsible for students' development is one of the most powerful agents effective on learning and achievement, but this effect can be either positive or negative (Hattie \& Timperley, 2007). Positive verbal feedback significantly accelerates motivation, while negative feedback significantly undermines the main motivation (Koka \& Hein, 2003, 2006). It is suggested that effective feedback during choral rehearsals directly affects motivation. During choral rehearsals, individual feedback is more useful in motivating students to the learning process than general feedback (Stamer, 2009).

A general public psychology and intuitive approaches of motivation often see interest, attention, learning, thinking and performance phenomenon as an important aspect of motivation. In addition, many people realize how to process effective learning and believe that they know what they are dealing with (Brophy, 2004). Interest can be expressed as volunteering to engage in an activity, liking/fancying performing an activity or a tendency to engage in an activity. Interest is described under two headings as personal interest and situational interest. In individual interest, individual propensity to a specific topic or area occurs without any pressure to complete a subject or activity and is relatively stable. Situational interest requires a special kind of temporary and situational attention to a subject [a very short attention span] and in this sense does not seem very stable. Situational interest, on the other hand, is generated by interesting environmental conditions, such as surprise, novelty, complexity, and ambiguity. Interest is not a type of motivation; rather, it has an effect on motivation (Pintrich \& Schunk, 2002; Renwick \& McPherson, 2002; Urdan \& Turner, 2005). "That, in each" other's absence, individual and situational interest may have especially important roles. Well-developed individual interest in an area may help individuals to cope with relevant but boring texts or presentations, and situational interest elicited by texts or presentations may maintain motivation and performance even when individuals have no initial interest in the topic. Furthermore, situational interest may ultimately develop into individual interest (Hidi, 2001). Although, in a sense, intrinsic motivation exists within individuals, it is made up of the relationship between individuals and activities. People may be intrinsically motivated for some activities, while others can not; intrinsic motivation exists by the link between a duty and a person so some authors define it in terms of pleasure from one's commitment to the duty, while others define it in terms of the attractiveness of duties (Ryan \& Deci, 2000). Behaviors motivating a group of students may fail to motivate another group... Interesting tasks [content] often stimulate intrinsic motivation for learning and students' adaptation to duties stimulating their motivation and attracting them also encourage choir educators during work. Students should be encouraged so that they become successful in adaptation for solving problems related to difficult tasks. It was suggested that during choral rehearsals, students' success further positively affects teachers (Stamer, 1999).

Students need to feel that they managed to achieve improvements. If students can learn fast and accurately and show new learning related to the subject, improvement can be measured. The right start [students' readiness level] should be determined by identifying what they already know. Students should be told what they will learn until the end of the lesson. Educator should determine what students can do and help by modeling/showing relevant examples. If students work in pairs or groups, then they feel that there is a good chance of success. The more a student feels success, the more successful she/he will be in the future (Tileston, 2004). Some situational factors affect achievement motivation such as incentives, control and opportunity. 
There are different definitions of anxiety in the literature. In general, anxiety is a universal feeling and experience individuals have at certain times of their lives. This behavior, shown by an individual against situations perceived as if something bad will happen in the future and in the case of which individuals feel insecure, expresses feelings of indecision for future, confusion, fear, anxiety, pessimism and despair and briefly causes an individual to fail in life. According to Hill and Sarason (1966), anxiety is a feeling that often upsets an individual in normal life, negatively affects the individual's behavior to a large extent and causes incompatibility, always showing itself in school environment (Erözkan, 2004; Aydın \& Zengin, 2008). Factors affecting the level of anxiety are responsibility, time and proximity. If the activity is an activity which involves responsibility, students should be encouraged to undertake the task. Responsibilities make tasks important and time affects students regardless of whether they have begun the task or not. If time is short and students feel that they have very little chance to complete the task successfully, then students take no action for this task. If students have too much time, they postpone fulfilling their tasks to a later date. Therefore, students' development and approaches toward an activity should be supervised. Educators' fondness for students is likely to be one of the best motivators. Students want to be accepted by their teachers and tend to continue to do the task when they feel that you are on their side. If you desire to be with them while they are completing their tasks, then they will feel your commitment to the task (Tileston, 2004). When educators focus on monitoring, supervising and helping, where necessary, during management of a learning process, their level of anxiety may be lowered or eliminated. Weiner (1972) suggests that in Hunter's model, level of anxiety is a variable of motivation. A certain amount of anxiety or stress is required to motivate students in the learning process. Motivation can be increased by raising students' level of anxiety or stress to a certain extent. According to Mullins (1981) and Peggie (1982), students can be stimulated by fear used by an educator as a motivating factor or motivation to learn can be increased by fear or threat (Stamer, 1995).

\subsection{Motivation Approaches}

Intrinsic motivation refers to engaging in an activity for its own sake, for the pleasure and satisfaction derived from participating in it. Extrinsic motivation refers to engaging in an activity for instrumental reasons rather than for the intrinsic qualities of the activity (Ryan \& Deci, 2000). Some behavior is seemingly motivated for its own sake, or by personal satisfaction at having done a good job, or by larger feelings of competence and control. This is termed intrinsic motivation. What intrinsically motivates one choir member may not motivate another. People with a strong need for achievement prefer tasks that provide immediate and abundant feedback and tasks that are difficult but accomplishable. This would seem to define many choristers' motivation for singing in a choir. So we see that external rewards may backfire if given to choir members who are already intrinsically motivated. Such rewards, when seen as controlling, might result in a decrease in motivation. Leaders often assume that they already know what works in motivating their choir, but some approaches are more effective than others for producing certain outcomes. There are four broad categories of motivation (Emmons \& Chase, 2006).

- Need approaches

- Situational approaches

- Individual difference approaches

- Conscious and directed choice approaches

○ The expectancy Theory

$\circ$ Goal Setting

- Self determination Theory (added)

The first four of Maslow's hierarchy of needs defined in eight stages are deficiency needs and the other four are growth needs. Deficiency needs; need for physiological maintenances: safety needs, belongingness and love and esteem needs, cognitive needs, aesthetic needs, self-actualization, self-transcendence (Koltko-Rivera, 2006; Harper \& Guilbault, 2008; Littrell, 2012). By the Maslow theory, the choir can be included in a scenario of life quality and social balance, since the participation in the activities that promote the self-esteem increase and the self-fulfillment sense, constitute an individual's formation significant aspect. In that perspective, the choir helps the person in its personal growth and then in its motivation (Fucci Amato, 2007).

One of the important approaches of leadership is situational approach. The basis of situational approach, developed by Hersey and Blanchard (1969), is related to the fact that different types of leadership behaviors are needed under different circumstances and to being more effective as a leader. It is the alignment of leader behaviors of an individual or group which one tries to influence with respect to performance requirements 
(Hersey, 2009; Esther, 2011). Some work in the community is more pleasing and more motivating than others. Vocal and musical behaviors of choristers are respected so those singing in choirs which have the same opinion have a high place on the list. These tasks include a lot of feedback in them and require use of the whole vocal and musical behaviors. If choristers have extremely positive or extremely negative tendencies, chorus director will hardly make an impact on the choristers. When choristers believe why they join to sing, they will get more satisfaction and be pleased more. Pleased choristers will also most likely continue to participate in choral rehearsals with more enthusiasm (Emmons \& Chase, 2006).

It tries to explain the measures to be taken to minimize individual differences observed in settings where teaching with a group takes place, such as a school, so that this will benefit the school and the community. There are many differences between students in schools in terms of general ability, personality, socio-economic status, attitude, success, etc. For Emmons and Chase (2006), individual difference approaches, various motives define the consistent differences between people. For example, people with a strong need for achievement like taking responsibility for solving problems and accomplishing socially acceptable endeavors, and they prefer tasks that provide immediate feedback. The leader should focus on the comparative strength of these motives belonging to his or her choristers.

The expectation-value approach of motivation represents that people should have voluntary efforts with respect to learning (Eccles \& Wigfield, 2000). Motivational research in academic subjects has demonstrated that when students are interested in an activity and feel free to choose whether or not to do it, they are more likely to engage in higher-level cognitive functioning and it easier to concentrate, persevere, and enjoy their learning (Renwick \& McPherson, 2002). Students' strategies regarding expectation-value perceptions aim at one of four general approaches in order to deal with their class tasks, depending on students' achievement expectations and task values. Students' expectations with regard to classroom activities and behaviors regarding task values include finding attractive, hiding feelings, avoidance and refusal (Brophy, 2004). In relation to expectancy theory for motivation, the chorus director should explain the relationship between choristers' efforts and resulting performance level, convince choristers on advantages [awards], which are more important than their efforts and be in consensus (Emmons \& Chase, 2006). Two key factors, including students' expectancy of success in a task they are asked to do and the value the individual attaches to success in that task are generated. The higher the possibility of success is felt, the higher the incentive value of the target and motivation levels of individuals (Dörnyei, 2001).

When applied in an effective manner; Goal setting is a powerful motivational technique (Bandura \& Wood, 1989; Brophy, 2005; Reeve, 2009). The process begins with the target state. Setting goals and taking responsibility to achieve these goals increase students' performance levels. Goals are more effective when they are close to the center, rather than far, and when they are engaging rather than special, very easy and very difficult [hard but can be achieved by working] (Brophy, 2004, 2005; Locke \& Latham, 2006; Adair, 2006; Lunenburg, 2011). Goal setting is the easiest and most familiar system of motivation. It directs attention, Marshalls effort, strengthens persistence, and helps each individual singer to develop strategies for achievement and not to cease an effort until the goal is reached. The director should have valid authority, should be known to have confidence in the choristers, should have provided clear musical performance standards and goals. Followers exert the greatest effort when they receive feedback on their progress toward meeting the goals (Emmons \& Chase, 2006).

Self-determination theory is associative in terms of the fact that both internal and external motivation complement student's task performance and task completion. Intrinsically motivated learning is undertaken solely for its own sake, in contrast to the many forms of extrinsically motivated behaviour, where factors such as extrinsic utility value, fear of failure, or expected rewards may control the learning process. Human motivation can constantly exist between or coexist with intrinsic and extrinsic/controlled self-determination (Ryan \& Deci, 2000; Dorner, 2001; Gagne \& Deci, 2005; Guay et al., 2010). According to SDT, humans have three core psychological needs: competence, relatedness, and autonomy. Competence is the belief that one has the ability to influence important outcomes. Relatedness is the experience of having satisfying and supportive social relationships. Autonomy concerns the experience of acting with a sense of choice, volition, and self-determination (Gagne \& Deci, 2005; Seifert \& Sutton, 2009; Stone et al., 2009).

\subsection{Purpose}

A need exists for a valid and reliable measure of motivation of choir that is informed by a robust psychological theory as well as the most current research in choir eğitimi ve practice. Such a contribution could advance significantly our understanding of how individuals develop into competent chorus member and music teacher. The aim of this study was to determine preservice teachers' perceptions of effective motivational strategies in 
choir classes in accordance with their own reports and develop a Chorus Motivation Scale (CMS) whose construct validity and reliability were tested. A questionnaire was designed by interpreting, in a holistic structure, five motivational variables defined by Stamer (1995) with regard to motivational variables that are effective in choir training as well as motivational approaches widely used in choir training, suggested by Emmons and Chase (2006).

\section{Method}

The Method section describes in detail how the study was conducted, including conceptual and operational. The research population consisted of 24 students from Sub-Department of Music Education, Department of Fine Arts Education, Faculty of Education of state universities in seven geographical regions of Turkey. The sample was 2nd, 3rd and 4th year students studying at Sub-Department of Music Education, Department of Fine Arts Education, Faculty of Education of Abant Izzet Baysal University, Gazi University, Dokuz Eylül University, İnönü University, Marmara University, Mehmet Akif Ersoy University, Necmettin Erbakan University, Ondokuz Mayıs University and Uludağ University during the academic year of 2011-2012.

40 students on their 2nd year at Sub-Department of Music Education, Department of Fine Arts, Gazi Faculty of Education of Gazi University were asked to write an essay on "What motivates you during chorus training lessons?". Content analysis was carried out on essays and students' opinions thought to be related to motivational strategies were identified. Items defining motivation variables with respect to these findings were created and the items of Chorus Motivation Scale (CMS) were determined by interpreting them, in a holistic structure, using five motivational variables defined by Stamer (1995) as well as motivational approaches widely used in choir training, suggested by Emmons and Chase (2006). The items were classified under four headings: theories of motivation, extensions motivating students to learn, approaches which can be observed/expected on students' motivation effective chorus director characteristics. When creating items of the scale, attention was paid to ensuring that statements are simple and easy to understand. Scale items were created according to 5-point Likert-type scale and prepared in such a way that the students can choose one of the following options: "increases a lot", "increases", "does not affect", "reduces", "greatly reduces" (Tavşancıl, 2010). A comprehensive literature search was conducted with respect to creating possible items of Choir Motivation Scale, internal validity of its content, face validity and construct validity, and a trial scale of 51 items was created by taking account of corrections, criticisms and suggestions of experts (faculty members) during all stages of the study (Fraenkel \& Wallen, 2009).

The researcher visited each school to administer the Choir Motivation Scale (CMS) Survey to all participating students. Only participants who completed an informed assent form approved by the University institutional review board and the local school district as well as a kendi consent form participated in this study. Students were asked to read each statement carefully and to indicate the effectiveness of each statement in motivating them to learn in the choral rehearsal by circling one of the five-point Likert responses.

During the investigation, data for the pilot study was obtained from 64 students. A total of 794 students, including 340 students for Exploratory Factor Analysis (EFA) and 390 students for Confirmatory Factor Analysis (CFA), participated in the study. 394 (49.6\%) participants were male and $400(50.3 \%)$ were female.

The pilot scale consisting of 51 questions was applied to 64 students. Correlation coefficients of 51 items, which is a prerequisite of exploratory factor analysis, were checked. Items with moderate or high degree of correlation between them $r>|0.4|$ were identified and five items were removed from the scale.

Factor analysis allows determination of factor characteristics and factor numbers taking account of the responses of the data obtained. During preliminary factor analysis of the research, the results of factors with an eigenvalue larger than 1 were studied and evaluated (Kaiser Method). According to this method, data describes a 9-factor structure. In nine-factor structure, most factors contain 1 or 2 items. Scree plot, another method that determines the number of factors in a scale, describes as 4 or 5 factors. Considering which factor is more compatible with theoretical structure, it was decided that the most appropriate factor structure that describes the scale would be 4-factor structure, i.e., "leadership, chorus director/student attention, achievement, anxiety". Exploratory factor analysis was conducted to provide sufficient evidence for developing a hypothesis on the number of factors underlying the data and determine nature and number of factors describing covariance between variables. The construct validity of the questionnaire was tested using Confirmatory Factor Analysis (CFA). 


\section{Procedure}

\subsection{Preliminary Reliability and Correlational Analyses}

Kaiser-Meyer-Olkin value allows assessment of the suitability of data structure for factor analysis of the sample in terms of size. A value of .93 indicates that each variable in the scale can be perfectly predicted by the other variables. The remaining 42 items produced a Kaiser-Meyer-Olkin Measure of Sampling Adequacy of .861; Bartlett's Test of Sphericity was found to be significant $(\mathrm{p}=.001(\chi 2=6545, \mathrm{df}=861))$.

As a result of exploratory factor analysis, four items with factor loadings of less than .40 loaded to other factors $(34,18,5$ and 1) were removed from the scale (Şencan, 2005; Costello \& Osborne, 2005; Seven, 2011; Çokluk et al., 2012). As a result of exploratory factor analysis, 42 items remained after the removal of four items. As seen from Table 2 (42 items), in view of Skewness and Kurtosis descriptive statistics, it is clear that chorus director/student attention, achievement and anxiety factors have normal distribution, whereas a high Kurtosis value for leadership factor indicates that it slight deviated from normal distribution (Kurtosis $>1.00$ ). The range of Cronbach's alpha reliability coefficients across the hypothesized subscales was good ( $\alpha=.73$ to .94 ).

Table 1. Skewness and Kurtosis descriptive statistics for Chorus Motivation Scale

\begin{tabular}{lcccccccc}
\hline Variable & $\mathrm{n}$ & Min. & Max. & $\overline{\boldsymbol{x}}$ & sd & Skewness & Kurtosis & $\alpha$ \\
\cline { 1 - 5 } Leadership (24 items) & 340 & 1.38 & 5.00 & 4.06 & .56 & -1.07 & 2.86 & 94 \\
Director/student attention (9 items) & 340 & 2.11 & 5.00 & 4.08 & .54 & -.61 & .50 & 84 \\
Achievement (5 items) & 340 & 1.80 & 5.00 & 4.14 & .56 & -.50 & .29 & 73 \\
Anxiety. (4 items) & 340 & 1.00 & 5.00 & 2.04 & .86 & 1.03 & .69 & 73 \\
\hline
\end{tabular}

\subsection{Construct Validity and Confirmatory Factor Analysis}

In contrast to exploratory factor analysis, confirmatory factor analysis is used to verify the number of underlying dimensions of a questionnaire when the design of the measure is informed by theory. As a result of exploratory factor analysis, initial measurement model was defined by four factor, including leadership, chorus director/student attention, achievement and anxiety. The measurement model consisting of initial 42-items (observed) combined with four latent structures and model fit summary fulfilled the criteria for Absolute fit indices, however, failed to show a good fit as a whole. However, as previously discussed, a measurement model can fulfill the criteria for a good fit if certain requirements are met (Hair et al., 2006, Brown, 2006; Bayram, 2010). Index values of CFA 1 work, initial measurement model $\left(\chi^{2}=1759.82 ; \chi^{2} / \mathrm{df}=2.16 ; \mathrm{CFI}=0.83 ; \mathrm{TLI}=.82\right.$; RMSEA $=.05$ ) did not show adequate model fit for the experimental data. In general model, $\chi^{2}=1759.82, \mathrm{df}=813$, $\mathrm{p}=.001$ associated with chi-square value were obtained. P-value does not show the fit between covariance matrix observed in experimental data and the estimated covariance matrix (Hair et al., 2010). However, statistical test accuracy of chi-square $\left(\chi^{2}\right)$ and $\left(\chi^{2} / \mathrm{df}\right)$ values of the hypothesized model should be considered (Byrne, 2010). More precisely, decreases in chi-square $\left(\chi^{2}\right)$ and $\left(\chi^{2} / \mathrm{df}\right)$ values show modification index (Bayram, 2010).

Model-1: Measurement model can be changed by exploring standardized residuals, modification indices and standard loading estimates. Path estimates interconnecting structures and whether redefining (customization) is necessary are exemplified together with the model fit indices so that each of these measurements becomes precise. Standard residuals represent the differences between covariance observed and estimated by least-squares fit residuals. A significant standard residual is 4 or a larger absolute value. In order to eliminate any other problem associated with two items, loaded estimates and modification indices should be investigated and the items related to standard residuals between 2, 5 and 4 should be taken into account (Hair et al., 2006).

In modifications related to evaluating model fit based on standard residuals, twelve indicators were deleted (Note 1). After these modifications were performed, fit indice values for CFA13=Model-1 $\left(\chi^{2}=740.57 ; \chi^{2} / \mathrm{d} f=1.85\right.$; $\mathrm{CFI}=.90 ; \mathrm{TLI}=.89$; RMSEA=.04) were determined. According to model fit indice suggestions of $\mathrm{Hu}$ and Bentler (1999), Brown (2006), $\chi^{2} / \mathrm{df}$ and RMSEA values achieved perfect fit, while CFI and TLI values achieved acceptable threshold values. 
Table 2. Goodness-of-fit results for measurement Model-1

\begin{tabular}{|c|c|c|c|c|c|c|c|c|c|c|}
\hline Model & $\chi^{2}$ & $\chi 2 / \mathrm{df}$ & $\mathrm{p}$ & CFI & TLI & RMSEA & Items Deleted & $\begin{array}{c}\text { Reason for } \\
\text { deletion }\end{array}$ & $\Delta \chi 2$ & I.N \\
\hline CFA1 & 1759.82 & 2.16 & $<.001$ & .83 & .82 & .05 & 7 & h. std. res. & - & 42 \\
\hline CFA2 & 1660.38 & 2.14 & $<.001$ & .84 & .83 & .05 & 43 & h. std. res. & 99.44 & 41 \\
\hline CFA3 & 1.579 .50 & 2.15 & $<.001$ & .84 & .83 & .05 & 27 & Large MI & 80.88 & 40 \\
\hline CFA4 & 1451.28 & 2.08 & $<.001$ & .85 & .84 & .05 & 23 & Large MI & 128.22 & 39 \\
\hline CFA5 & 1359.38 & 2.06 & $<.001$ & .86 & .85 & .05 & 8 & Large MI & 91.9 & 38 \\
\hline CFA6 & 1287.25 & 2.06 & $<.001$ & .86 & .85 & .05 & 44 & h. std. res. & 72.13 & 37 \\
\hline CFA7 & 1218.48 & 2.07 & $<.001$ & .87 & .86 & .05 & 22 & Large MI & 68.77 & 36 \\
\hline CFA8 & 1118.07 & 2.01 & $<.001$ & .87 & .87 & .05 & 16 & h. std. res. & 100.41 & 35 \\
\hline CFA9 & 1048.52 & 2.01 & $<.001$ & .88 & .87 & .05 & 31 & Large MI & 69.55 & 34 \\
\hline CFA10 & 957.69 & 1.95 & $<.001$ & .89 & .88 & .05 & 3 & Large MI & 90.83 & 33 \\
\hline CFA11 & 881.67 & 1.92 & $<.001$ & .89 & .88 & .05 & 30 & h. std. res. & 76.02 & 32 \\
\hline CFA12 & 816.09 & 1.90 & $<.001$ & .90 & .89 & .05 & 41 & Large MI & 65.58 & 31 \\
\hline CFA13 & 740.57 & 1.85 & $<.001$ & .90 & .89 & .04 & - & - & 75.52 & 30 \\
\hline
\end{tabular}

Note. $\mathrm{N}=370$, CFA13=Model-1; h. std. res: high standard residuals; large M.I: large modificiation index; I.N.: item number.

Model-2: AMOS can produce results on upon addition of which correlations the model can have better fit values. Model fit indices can be improved by adding covariances related to error variances by examining improvement indices (modification indices) from text outputs (Bayram, 2010; Meydan \& Şeşen, 2011). As shown in Table 3; in this study, modification indices related to error variances were examined and a total of 5 covariances, including four in Leadership factor (3-4, 5-11, 6-10, 7-12), and one (18-19) in chorus director/student attention factor, were performed. After covariances related to error variances were added, fit index values for Model 2 were determined as follows: $\chi^{2}=685.67 ; \chi^{2} / \mathrm{df}=1.74, \mathrm{CFI}=.92, \mathrm{TLI}=.91, \mathrm{RMSEA}=.04$. According to the model fit indice suggestions, $\chi^{2} / \mathrm{df}$ and RMSEA can be interpreted as perfect fit, while CFI and TLI values can be said to be above the acceptable threshold values. Under .95 and close to suggestions of Hu and Bentler (1999); Brown (2006), they can be interpreted as good/logical fit indices.

Table 3. Goodness-of-fit indices for measurement Model-2

\begin{tabular}{|c|c|c|c|c|c|c|c|c|c|c|}
\hline Model & $\begin{array}{c}\text { Covariance } \\
\text { items }\end{array}$ & $\chi^{2}$ & $\mathrm{df}$ & $\chi^{2 / \mathrm{df}}$ & $\mathrm{p}$ & CFI & TLI & RMSEA & $\Delta \chi^{2}$ & $\Delta \mathrm{df}$ \\
\hline CFA 13 & Model 1 & 740.57 & 399 & 1.85 & $<.001$ & .90 & .89 & .05 & - & - \\
\hline CFA 14 & $33-28$ & 725.21 & 398 & 1.82 & $<.001$ & .91 & .90 & .05 & 15.36 & 1 \\
\hline CFA 15 & $45-47$ & 712.79 & 397 & 1.79 & $<.001$ & .91 & .90 & .05 & 27.77 & 1 \\
\hline CFA 16 & $14-10$ & 702.98 & 396 & 1.77 & $<.001$ & .91 & .90 & .05 & 37.58 & 1 \\
\hline CFA 17 & $26-38$ & 693.77 & 395 & 1.75 & $<.001$ & .91 & .91 & .05 & 46.79 & 1 \\
\hline CFA 18 & $48-35$ & 685.67 & 394 & 1.74 & $<.001$ & .92 & .91 & .04 & 54.90 & 1 \\
\hline Model-2 & - & 685.67 & 394 & 1.74 & $<.001$ & .92 & .91 & .04 & 54.90 & - \\
\hline
\end{tabular}

Note. Model customized with error covariances=Model 2.

\section{Results and Implications}

Results suggested that the four-factor model -leadership, director/student attention, achievement, and anxietywas the best overall fit to the data. AMOS 20 was used to estimate the models (Albright \& Hun, 2009). Maximum likelihood estimation was used to determine the models. Model Measurement factor variance equation was set to one.

In Table 2, in CFA1 measurement model, modification indices were examined and 12 items related to standard residuals between 2, 5 and 4 were removed, resulting in Model-1. When chi-square $(\chi 2=1759.82)$ value for modified (CFA1) model was compared with Model-1 chi-square value difference $(\Delta \chi 2=1019.25)$ and the 
Model-2 chi-square value $(\Delta \chi 2=1074.15)$ difference, CFA1 initial model gave a positive/good response with regard to chi-square statistical test sensitivity. When certain covariances were performed between error variances of items, factor structure showed slightly better fit indices, resulting in Model-2 final model. In view of suggested standard residuals, certain pairs of items can be further removed from the scale, however, removal of these items from the scale would be dangerous for internal consistency of the scale. Estimated degrees of correlation between leadership, chorus director/student attention and achievement dimensions were extremely high, and in some cases, almost near-perfect coefficients $(.86, .78, .80)$ emerged, so discriminant validity seems poor (Harrington, 2009; Miksza, 2012).

In Table 4, Model-1 initial Cronbach's alpha reliability coefficients were as follows: Leadership: .93; chorus director/student attention: .85; achievement: .70 and anxiety: .71. Model-2 Cronbach's alpha reliability coefficients were $.91, .78$, and .71 for leadership, chorus director/student attention and anxiety, respectively, whereas achievement seems slightly poor with .64 .

Table 4. Initial and final model reliability statistics results for Chorus Motivation Scale

\begin{tabular}{lccccc}
\hline CFA1 Dimensions (initial) & Cronbach's Alpha & Mean & Variance & $\begin{array}{c}\text { Standard } \\
\text { Deviation }\end{array}$ & $\begin{array}{c}\text { Number of } \\
\text { items }\end{array}$ \\
\hline Leadership & .93 & 97.23 & 186.67 & 13.66 & 24 \\
Director/student attention & .85 & 36.38 & 28.04 & 5.29 & 9 \\
Achievement & .70 & 20.08 & 6.83 & 2.61 & 5 \\
Anxiety & .71 & 8.47 & 11.83 & 3.44 & 4 \\
\hline CFA18 Dimensions (Final) & & & & 16 \\
\hline Leadership & .91 & 65.25 & 86.79 & 9.31 & 6 \\
Director/student attention & .78 & 24.61 & 12.71 & 3.56 & 4 \\
Achievement & .64 & 16.62 & 4.74 & 2.17 & 4 \\
Anxiety & .71 & 8.47 & 11.83 & 3.44 & 4 \\
\hline
\end{tabular}

Path diagrams of all models with standardized coefficients are presented in. Goodness-of-fit statistics for the models estimated are presented in Table 5. The minimum fit function chi-square was significant for each model $(\mathrm{p}<.001)$. Consequently, researchers rely more commonly on additional absolute fit indices such as the Root Mean Square Error of Approximation (RMSEA) and Standardized Root Mean Square Residual (SRMR) well as incremental fit indices such as the Comparative Fit Index (CFI); Tucker-Lewis Index (TLI) (see Brown, 2006; $\mathrm{Hu} \&$ Bentler, 1999). Upon examining the sum of empirical evidence, the goodness-of-fit indices, estimated coefficients, and model comparisons indicate that the four-factor model is the best fit to the data. However, the degree of correlation estimated between the latent variables method, behavior, and social influences is extremely high and in some cases nearly perfect (coefficients .78 to .86) and therefore suggests poor discriminant validity.

Table 5. Summary of Goodness-of-fit statistics for Determining Basic Model

\begin{tabular}{|c|c|c|c|c|c|c|c|c|c|c|c|c|}
\hline Model & $\chi^{2}$ & $\mathrm{df}$ & $\chi^{2 / \mathrm{df}}$ & $\mathrm{p}$ & RMSEA & CI & $p$ Close & SRMR & TLI & CFI & $\Delta \chi^{2}$ & $\Delta \mathrm{df}$ \\
\hline CFA1 & 1759.82 & 813 & 2.16 & $<.001$ & .05 & $.05 ; .06$ & .00 & .05 & .82 & .83 & - & - \\
\hline Model-1 & 740.57 & 399 & 1.85 & $<.001$ & .04 & $.04 ; .05$ & .70 & .0 & .89 & .90 & 1019 & 414 \\
\hline Model-2 & 685.67 & 394 & 1.74 & $<.001$ & .04 & $.03 ; .05$ & .93 & .04 & .91 & .92 & 1074 & 419 \\
\hline
\end{tabular}

Note. CFA1: null model 42 items; Model-1=Hypothesised 30-Items; $\chi 2=$ minimum fit function chi-square; $\mathrm{df}=\mathrm{degrees}$ of freedom; $\chi 2 / \mathrm{df}:=$ the ratio of the degree of freedom chi-square; RMSEA=root mean square error of approximation; $\mathrm{CI}=90 \%$ confidence interval; $\mathrm{p}$ Close $=\mathrm{p}$ of close fit; $\mathrm{SRMR}=$ standardized root mean square residual; $\mathrm{CFI}=$ comparative fit index; TLI=Tucker-Lewis Index; $\Delta \chi 2=$ difference between chi-square value; $\Delta \mathrm{df}=$ difference value degrees of freedom; Model-2=Final Measurement Model; four factor=Leadership, director/student attention, achievement and anxiety. 
This study was based on eight motivational approaches-theories, including "intrinsic and extrinsic, needs, expectation-value, goal setting, situational approaches and different individual approaches" and self-determination theory added, which are effectively used in choir training and practices. The questionare, prepared with a holistic understanding using students reports on what motivates them to learn better during choir classes, the motivation variables (Stamer, 1995), motivation variables and motivation approaches, was described in a total of 30 items, including 16 items for leadership, 6 items for director/student attention, 4 items for achievement and 4 items for anxiety.

With regard to Stamer's five motivational variables, effective motivation strategies which motivate students to learn in choir training were described in four factors in this study. In this study, Turkish preservice teachers were not affected by the items, by which it was aimed to increase motivation of some students by increasing anxiety or tension level, described as a motivational variable by Hunter (1967) and Stamer (1995, 2009). Items described by preservice music teachers at anxiety level were items describing anxiety factor containing "responsibility, time and fondness", which directly prevents motivation to learn. Gözen (2010) argues that in choirs consisting of a community, which rehearses under the management of a choir director, harmonious coexistence of choristers with the director in both musical and personal sense affects the choir's success as well as individuals' mental states. In this context, during all choral rehearsals carried out to improve choral music and polyphonic chorus training, conflicts which may hinder communication should be avoided, and verbal and nonverbal communication dimensions, which will support success and requirements of this training, should be utilized.

Chorus Motivation Scale, classified under initial development category, is defined as a study which “... tested a structure which hasn't been tested before in many aspects such as its preparation, sample group, method, dimensions, items covered by dimensions..." and in which Exploratory Factor Analysis (EFA) and Confirmatory Factor Analysis (CFA) methods were employed. When research is carried out with identical-similar-different groups based on the method, findings and results of Chorus Motivation Scale, this study should be evaluated within the scope of "a model study", considering that such research may turn out to be consistent with any of structural support or structure development studies (Appendix).

\section{Acknowledgments}

This article is based on the author's doctoral dissertation, "Student Perceptions of Effective Motivation Strategies in Chorus Training" completed at the University of Necmettin Erbakan University, in 2013. I would like to thank to Dr. Oktay Mercimek for statistics help.

\section{References}

Adair, J. (2006). Etkili motivasyon: İnsanlardan en iyi verimi nasil alabilirsiniz. İstanbul: Babali Kültür Yayıncılı̆̆ı.

Albright, J., \& Hun, M. P. (2009). Confirmatory factor analysis using amos, lisrel, mplus, and sas/stat calis. Working Paper. Indiana University.

Ames, C. A. (1990). Motivation: What teachers need to know. Teachers College Record, 91(3), 410-421.

Amoto, R. C., \& Neto, J. (2007). Choir conducting: Human resources management and organization of the work. In Proceeding of the 18th. Annual production and Operations Management Society Conference. Dallas, Texas, USA.

Amoto, R. C., \& Neto, J. (2008). The role of the choir conductor in motivating his group: Conceptual revision, suggestion, a perspective of music undergraduate students. In Proceeding of the 19th. Annual production and Operations Management Society Conference. California, USA.

Amoto, R. C. F. (2011). The Maestro as leader: Bases of authority, leadership styles and emotional intelligence in choral conductors. In Proceeding of the 22nd. Annual Production and Operations Management Society Conference. Nevada, USA.

Aydın, S., \& Zengin, B. (2008). Yabancı dil öğretiminde kaygi: Bir literatür özeti. Journal of Language and Linguistic Studies, 4(1), 81-94.

Bandura, A., \& Wood, R. (1989). Effect of perceived controllability and performance standards on self-regulation of complex decision making. Journal of Personality and Social Psychology, 56(5), 805-814. https://doi.org/10.1037/0022-3514.56.5.805

Bayram, N. (2010). Yapısal eşitlik modellemesine giriş amos uygulamalari. Bursa: Ezgi Kitabevi. 
Boekaerts, M. (2010). The crucial role of motivation and emotion in classroom learning. In H. Dumont, \& F. Benavides (Eds.), Educational Research and Innovation. OECD Publishing. https://doi.org/10.1787/9789264086487-6-en

Bowman, R. F. (2007). How can students be motivated: A misplaced question? Clearing House, 81(2), 81-86. https://doi.org/10.3200/TCHS.81.2.81-86

Bowman, R. F. (2011). Rethinking what motivates and inspires students. The Clearing House: A Journal of Educational Strategies, Issues and Ideas, 84(6), 264-269. https://doi.org/10.1080/00098655.2011.592164

Brewer, E. W., \& Burgess D. N. (2005). Professor's role in motivating students to attend class. Journal of Industrial Teacher Education, 42(3), 23-47.

Brophy, J. (2004). Motivating students to learn. Mahwah, NJ: Lawrence Erlbaum.

Brophy, J. (2005). Goal theorists should move on from performance goals. Educational Psychologist, 40(3), 167-176. https://doi.org/10.1207/s15326985ep4003_3

Brown, T. A. (2006). Confirmatory factor analysis for applied research: Methodology in the social sciences. New York, NY: Guilford.

Byrne, B. M. (2009). Structural Equation Modeling with AMOS: Basic concepts, applications, and programming. New York, NY: Routledge Taylor and Francis Group.

Costello, A. B., \& Osborne, J. W. (2005). Best practices in exploratory factor analysis: Four recommendations for getting the most from your analysis. Practical Assessment Research and Evaluation, 10(7), 1-9.

Çevik, S. (1997). Koro eğitimi ve yönetim teknikleri. Ankara: Doruk Yayınevi.

Çokluk, Ö., Şekercioğlu, G., \& Büyüköztürk, Ş. (2012). Sosyal bilimler için çok değişkenli istatistik spss ve lisrel uygulamalari. Ankara: Pegem Akademi Yayınları.

De Masi, D. (2003). Criatividade e grupos criativos. Rio de Janeiro: Sextante.

DeVellis, R. F. (2003). Scale development theory and applications (2nd ed.). California: Sage Publications.

Dowsona, M., \& McInerneyb, D. M. (2003). What do students say about their motivational goals? Towards a more complex and dynamic perspective on student motivation. Contemporary Educational Psychology, 28, 91-113. https://doi.org/10.1016/S0361-476X(02)00010-3

Dörnyei, Z. (2001). Motivational Strategies in the Language Classroom. New York: Cambridge University Press. https://doi.org/10.1017/CBO9780511667343

Durrant, C. (2009). Communicating and accentuating the aesthetic and expressive dimension in choral. International Journal of Music Education, 27, 326-340. https://doi.org/10.1177/0255761409344374

Eccles, J. S., \& Wigfield, A. (2000). Expectancy-value theory of achievement motivation. Contemporary Educational Psychology, 25, 68-81. https://doi.org/10.1006/ceps.1999.1015

Egüz, S. (1981). Koro eğitimi ve yönetimi. Ankara: Ayyıldız Matbaası.

Emmons, S., \& Chase, C. (2006). Prescriptions for choral excellence: Tone, text, dynamic leadership. New York: Oxford University Press.

Erözkan, A. (2004). Üniversite ögrencilerinin sinav kaygisi ve başa çikma davranışlari. Muğla Üniversitesi Sosyal Bilimler Enstitüsü Dergisi, 12, 13-38.

Esther, M. (2011). Creating effective leaders through situational leadership approach (Applied Sciences Bachelor's Thesis, pp. 1-32). JAMK University.

Fraenkel, J. R., \& Wallen, N. E. (2009). How to design and evaluate research in education (7th ed.). Newyork: McGraw-Hill Published.

Fucci Amato, R., \& Neto Amato, J. (2007). The role of the choir conductor in motivating his group: Conceptual revision, suggestions, and a perspective of music undergraduate students. In Proceedings of the 18th. Annual Production and Operations Management Society (POMS) Conference. California.

Fucci Amato, R., \& Amato Neto, J. (n.d.). The role of the choir conductor in motivating his group: Conceptual revision, suggestions, and a perspective of music undergraduate students. In Proceedings of the 19th. Annual Production and Operations Management Society (POMS) Conference. POMS, La Jolla. 
Gagne, M., \& Deci, E. L. (2005). Self-determination theory and work motivation. Journal of Organizational Behavior, 26, 331-362. https://doi.org/10.1002/job.322

Ganschow, C. M. (2012). Secondary school choral conductors' self-reported beliefs and behaviors regarding fundamental choral elements and rehearsal approaches (Unpublished doctoral dissertation). Missouri-Kansas City.

Glynn, S. M., \& Koballa, T. R. (2006). Handbook of college science teaching. Arlington: National Science Teachers Association Press.

Grimland, F. (2005). Characteristics of teacher-directed modeling in high school choral rehear. Update: Applications of Research in Music Education, 24, 5. https://doi.org/10.1177/87551233050240010102

Gözen, A. G. (2010). A study of the communication between the conductor and the chorists in polyphonic chorus of different structures and purposes (Unpublished doctoral dissertation). Gazi Üniversitesi Eğitim Bilimleri Enstitüsü, Ankara.

Guay, F., Chanal, J., Ratelle, C. F., Marsh, H. W., Larose, S., \& Boivin, M. (2010). Intrinsic, identified, and controlled types of motivation for school subjects in young elementary school children. British Journal of Educational Psychology, 80, 711-735. https://doi.org/10.1348/000709910X499084

Gumm, A. (2004). The effect of choral student learning style and motivation for music on perception of music teaching style. Bulletin of the Council for Research in Music Education, 159, 11-22.

Guo, L. (2001). University choral rehearsals in China and Canada: A comparative case study (Unpublished master's thesis). Central China Normal University.

Hair J. F., Black, W. C., Babin, B. J., \& Anderson, R. E. (2010). Multivariate data analysis (7th ed.). Upper Saddle River, NJ: Prentice Hall.

Harper, F. D., \& Guilbault, M. (2008). Maslow's hierarchy of needs. In J. S. Neil (Ed.), Encyclopedia of Educational Psychology. Thousand Oaks, CA: Sage Publications.

Harrington, D. (2009). Confirmatory factor analysis. New York: Oxford University Press.

Hattie, J., \& Timperley, H. (2007). The power of feedback. Review of Educational Research, 77(1), 81-112. https://doi.org/10.3102/003465430298487

Hersey, P. (2009). Situational leaders: Excellence leadership. The Magazine of Leadership Development, Managerial Effectiveness, and Organizational Productivity, 6(2), 12.

Hersey, P., \& Blanchard, K. (1969). Life cycle theory of leadership. Training and Development Journal, 23(5), 26-34.

Hidi, S. (2001). Interest, reading, and learning: Theoretical and practical considerations. Educational Psychology Review, 13(3), 192-209. https://doi.org/10.1023/A:1016667621114

Hu, L., \& Bentler, P. M. (1999). Cutoff criteria for fit indexes in covariance structure analysis: Conventional criteria versus new alternatives. Structural Equation Modeling: A Multidisciplinary, 6(1), 1-55. https://doi.org/10.1080/10705519909540118

Hruska, B. J. (2011). Using mastery goals in music to increase student motivation. Update: Applications of Research in Music Education, 30(3), 3-9. https://doi.org/10.1177/8755123311418477

Jackson, D. L., Rebecca, P., \& Gillaspy, J. A. (2009). Reporting practices in confirmatory factor analysis: An overview and some recommendations. Psychological Methods, 14(1-6), 6-18. https://doi.org/10.1037/a0014694

Jensen, E. (2005). Teaching with the brain in mind (2nd ed.). Virginia: ASCD Publications.

Kocayörük, E. (2012). Self-determination theory and relationship between perception of parents and emotional well-being of adolescents. Türk Psikolojik Danışma ve Rehberlik Dergisi, 4(37), 24-37.

Koka, A., \& Hein, V. (2003). Perceptions of teacher's feedback and learning environment as predictors of intrinsic motivation in physical education. Psychology of Sport and Exercise, 4, 333-346. https://doi.org/10.1016/S1469-0292(02)00012-2

Koka, A., \& Hein, V. (2006). Perceptions of teachers' positive feedback and perceived threat to sense of self in physical education: A longitudinal study. European Physical Education Review, 12(2), 165-179. https://doi.org/10.1177/1356336X06065180 
Koltko-Rivera, M. E. (2006). Rediscovering the later version of maslow's hierarchy of needs: Self-transcendence and opportunities for theory, research, and unification. Review of General Psychology, 10(4), 302-317. https://doi.org/10.1037/1089-2680.10.4.302

Lai, E. R. (2011). Motivation: A literature review. Pearson's Research Reports, 1-41.

Lee, W., \& Reeve, J. (2012). Teachers' estimates of their students' motivation and engagement: Being in synch with students. Educational Psychology: An International Journal of Experimental Educational Psychology, 32(6), 727-747. https://doi.org/10.1080/01443410.2012.732385

Littrell, R. F. (2012). Academic anterograde amnesia and what Maslow really said. Centre for Cross Cultural Comparisons Working Paper, 3, 1-18.

Locke, E. A., \& Latham, G. P. (2006). New directions in goal-setting theory. Current Directions in Psychological Science, 15, 265. https://doi.org/10.1111/j.1467-8721.2006.00449.x

Lunenburg, F. C. (2011). Goal-setting theory of motivation. International Journal of Management, Business, and Administration, 15(1), 1-6.

Madura Ward-Steinman, P. (2010). Becoming a choral music teacher: A field experience workbook. New York: Routledge.

Maslow, A. H. (1954). Motivation and personality. New York: Harper.

Mergendoller, J. R., \& Packer, M. J. (1985). Seventh graders' conceptions of teachers: An interpretive analysis. The Elementary School Journal, 85(5), 581-600. https://doi.org/10.1086/461423

Meydan, C. H., \& Şeşen, H. (2011). Yapısal eşitlik modellemesi amos uygulamalari. Ankara: Detay Yayıncılık.

Miksza, P., Matthew Roeder, M., \& Biggs, D. (2010). Surveying Colorado band directors' opinions of skills and characteristics important to successful music Teaching. Journal of Research in Music Education, 57(4), 364-381. https://doi.org/10.1177/0022429409351655

Miksza, P. (2012). The development of a measure of self-regulated practice behavior for beginning and intermediate instrumental music students. Journal of Research in Music Education, 59(4), 321-338. https://doi.org/10.1177/0022429411414717

Özgül, İ. (2009). An analysis of the elementary school music teaching course in Turkey. International Journal of Music Education, 27(2), 116-127. https://doi.org/10.1177/0255761409102321

Öztop, S. (2007). A study on achieving target educational, social and cultural abilities by planned and programmed amateur chorus education (Unpublished master's thesis). Gazi Üniversitesi.

Öztürk, O. (2010). The communication between choir and choir conductor according to the perception of choir's members (Unpublished master's thesis). Çukurova Üniversitesi.

Pintrich, P. R., \& Schunk, D. H. (2002). Motivation in education theory, research, and applications (2nd ed.). Englewood Cliffs NJ: Prentice Hall Merrill.

Reeve, J. (2009). Understanding motivation and emotion (5th ed.). Hoboken, NJ: Wiley.

Renchler, R. (1992). Student motivation, school culture, and academic achievement what school leaders can do? Eugene: Eric Clearinghouse on Educational Management.

Renwick, J. M., \& McPherson, G. E. (2002). Interest and choice: Student-selected repertoire and its effect on practicing behavior. British Journal of Music Education, 19, 173-188. https://doi.org/10.1017/S0265051702000256

Riggs, A. L. (2011). A comparison of successful and less successful rehearsal strategies utilized in choral adjudicated sight-singing (Unpublished doctoral dissertation). Texas Tech University.

Robenstine, C. (1997). Can teachers motivate students? The Educational Forum, 61(4), 300-306. https://doi.org/10.1080/00131729709335274

Ryan, R. M., \& Deci, E. L. (2000). Intrinsic and extrinsic motivations: Classic definitions and new directions. Contemporary Educational Psychology, 25, 54-67. https://doi.org/10.1006/ceps.1999.1020

Secretan, L. H. K. (2005). Inspiring people to their greatness. Leader to Leader, 36, 11-14. https://doi.org/10.1002/ltl.122 
Seifert, K., \& Sutton, R. (2009). Educational Psychology. Zürich: Global Text Project is funded by the Jacobs foundation.

Seven, S. (2011). Okula uyum öğretmen değerlendirmesi ölçeğinin geliştirilmesi. Türk Eğitim Bilimleri Dergisi, 9(1), 29-42.

Shute, V. J. (2008). Focus on formative feedback. Review of Educational Research, 78(1), 153-189. https://doi.org/10.3102/0034654307313795

Stamer, R. A. (1995). Choral student perceptions of effective motivation strategies based on Madeline Hunter's motivation variables (Unpublished doctoral dissertation). University of Northern Colorado, Greeley.

Stamer, R. A. (1999). Motivation in the choral rehearsal: Asking students what motivates them and working with their responses stimulates the learning atmosphere in the choral rehearsal. Music Educators Journal, 85(5), 26-29. https://doi.org/10.2307/3399544

Stamer, R. A. (2009). Choral student perceptions of effective motivation strategies. Update: Applications of Research in Music Education, 28(1), 25-32. https://doi.org/10.1177/8755123309344113

Steele, N. A. (2010). Three characteristics of effective teachers. Update: Applications of Research in Music Education, 28(2), 71-78. https://doi.org/10.1177/8755123310361769

Stegman, S. F. (2001). Perceptions of student teachers in secondary choral classrooms. (JMTE) Journal of Music Teacher Education, 11, 12-20. https://doi.org/10.1177/105708370101100104

Stone, D. N., Deci, E. L., \& Ryan R. M. (2009). Beyond talk: Creating autonomous motivation through self-determination theory. Journal of General Management, $34(3), \quad 75$. https://doi.org/10.1177/030630700903400305

Svinicki, M. D. (2002). New directions in learning and motivation. New Directions for Teaching and Learning, 80, 5-27.

Sweet, A. P., \& Guthrie, J. T. (1996). How children's motivations relate to literacy development and instruction. National Reading Research Center, 49, 660-662.

Şencan, H. (2005). Sosyal ve davranişsal ölçümlerde güvenirlik ve geçerlilik. Ankara: Seçkin Yayınc1lık.

Tarr, L. L. (2005). Student success: Motivating middle school students through personal development. Da Vinci Learning Technologies, Inc.

Tavşancıl, E. (2010). Tutumlarin ölçülmesi ve spss ile veri analizi (4. Baskı). Ankara: Nobel Yayınevi.

Tileston, D. W. (2004). Training manual for what every teacher should know. California: A Sage Publications Company Corwin Press.

Tosi, H. L. (1991). A theory of goal setting and task performance. The Academy of Management Review, 16(2), 480-483. https://doi.org/10.2307/258875

Türkiye Cumhuriyeti YÖK. (2007). Müzik öğretmenliği lisans programı, öğretmen yetiştirme ve eğitim fakülteleri (1982-2007). Ankara: Yükseköğretim Kurulu Başkanlığı.

Urdan, T. C., \& Turner, J. C. (2005). Competence motivation in the classroom. In A. J. Elliot, \& C. S. Dweck (Eds.), Handbook of Competence and Motivation (pp. 297-317). New York: Guilford Press.

Varvarigou, M., \& Durrant, C. (2011). Theoretical perspectives on the education of choral conductors: A suggested framework. British Journal of Music Education, 28(3), 325-338. https://doi.org/10.1017/S0265051711000325

Worthington, R. L., \& Whittaker, T. A. (2006). Scale development research: A content analysis and recommendations for best practices. The Counseling Psychologist, 34, 806. https://doi.org/10.1177/0011000006288127

Zhukov, K. (2008). Exploratory study of approvals and disapprovals in Australian instrumental music teaching. International Journal of Music Education, 26(4), 302-314. https://doi.org/10.1177/0255761408096072 


\section{Note}

Note 1. A total of 12 items, including items 41, 43, 31, 44, 22, 23, 30, 27 for leadership, item 3, 7, 8 for chorus director/student attention and item 16 for achievement, were removed from the scale. Chorus motivation scale was customized with a total of 30 items after 12 items were removed.

\section{Appendix}

\section{CHORUS MOTIVATION SCALE (30 Items)}

\begin{tabular}{|c|c|c|c|c|c|}
\hline & $\begin{array}{l}\text { Increases my } \\
\text { motivation a lot }\end{array}$ & $\begin{array}{l}\text { Increases my } \\
\text { motivation }\end{array}$ & $\begin{array}{l}\text { Does not } \\
\text { affect my } \\
\text { motivation }\end{array}$ & $\begin{array}{l}\text { Reduces my } \\
\text { motivation }\end{array}$ & $\begin{array}{l}\text { Reduces my } \\
\text { motivation a lot }\end{array}$ \\
\hline $\begin{array}{l}1 \text { Chorus director attaches importance to exercises for bringing awareness on relaxation and } \\
\text { alertness so that my singing performance is sustained. }\end{array}$ & 口 & ם & 口 & 口 & 口 \\
\hline $\begin{array}{l}\text { 2. Chorus director continues his/her efforts until reaching the specified target during } \\
\text { rehearsals and helps me solve my problems by developing strategies for achievement. }\end{array}$ & 口 & ם & 口 & a & 口 \\
\hline $\begin{array}{l}\text { 3. Chorus director clearly makes suggestions for me to check myself so that I gain } \\
\text { responsibility, control and confidence for future learning. }\end{array}$ & ם & ם & 口 & ם & ם \\
\hline $\begin{array}{l}\text { 4. Chorus director uses appropriate metaphors to describe musical sounds I have failed to } \\
\text { achieve during rehearsals. }\end{array}$ & 口 & ם & 口 & 口 & ם \\
\hline $\begin{array}{l}\text { 6. Chorus director makes singing in the choir very endearing so while singing in the choir, so } \\
\text { I feel as though I'm a very different person. }\end{array}$ & ם & ם & ם & ם & ם \\
\hline $\begin{array}{l}\text { 7. Chorus director uses short, precise, understandable and clear language while making } \\
\text { corrections regarding feedback during rehearsals. }\end{array}$ & ם & ם & ם & ם & ם \\
\hline $\begin{array}{l}\text { 8. During rehearsals, chorus director includes selected choral works of world choral literature, } \\
\text { enriching my culture. }\end{array}$ & ם & ם & ם & ם & ם \\
\hline $\begin{array}{l}\text { 9. Chorus director reminds us of the basic principles related to bodily, spiritual and mental } \\
\text { relaxation so that I have an effective and efficient voice. }\end{array}$ & ם & ם & ם & ם & ם \\
\hline $\begin{array}{l}\text { 10. Chorus director keeps to schedule during rehearsals; } s / \text { he always sets clear performance } \\
\text { standards and goals with respect to chorus training process. }\end{array}$ & ם & ם & ם & ם & ם \\
\hline $\begin{array}{l}\text { 12. Chorus director encourages us to share our knowledge about chorus music in classroom } \\
\text { environment. }\end{array}$ & ם & ם & ם & ם & ם \\
\hline $\begin{array}{l}\text { 13. Choir director incorporates works of Polyphonic Contemporary Turkish Music } \\
\text { composers, which improve my technical skills, musical level and choral culture, into } \\
\text { rehearsals. }\end{array}$ & 口 & ם & 口 & ם & ם \\
\hline $\begin{array}{l}\text { 14. Chorus director pays attention to use verbal and nonverbal (vocal modeling and eye } \\
\text { contact) language of communication appropriately so that my level of attention increases } \\
\text { during rehearsals. }\end{array}$ & ם & ם & ם & ם & ם \\
\hline $\begin{array}{l}\text { 15. Chorus director is committed to choosing enthusiastic and exciting new choral works so } \\
\text { that we gain more knowledge about choral music. }\end{array}$ & ם & ם & ם & ם & ם \\
\hline $\begin{array}{l}\text { 16. Chorus director chooses works with genres which match my musical knowledge and may } \\
\text { interest me. }\end{array}$ & ם & ם & ם & ם & ם \\
\hline
\end{tabular}




\begin{tabular}{|c|c|c|c|c|c|}
\hline & $\begin{array}{l}\text { Increases my } \\
\text { motivation a } \\
\text { lot }\end{array}$ & $\begin{array}{l}\text { Increase } \\
\text { my } \\
\text { motivation }\end{array}$ & $\begin{array}{l}\text { Does not } \\
\text { affect my } \\
\text { motivation }\end{array}$ & $\begin{array}{l}\text { Reduces } \\
\text { my } \\
\text { motivation }\end{array}$ & $\begin{array}{l}\text { Reduces my } \\
\text { motivation } \\
\text { a lot }\end{array}$ \\
\hline $\begin{array}{l}\text { 17. Chorus director recommends me to take responsibility, share, cooperate and have a sense of } \\
\text { accomplishment, rather than compete with my friends. }\end{array}$ & ם & ם & ם & ם & ם \\
\hline $\begin{array}{l}\text { 18. Chorus director selects works that may improve my musical knowledge and talent but it is up } \\
\text { to me to be able to sing these works successfully. }\end{array}$ & ב & ם & 口 & ם & ם \\
\hline $\begin{array}{l}\text { 19. Chorus director always helps me by giving concrete examples on how to use musical } \\
\text { techniques and behaviors I already know (breathing, voice production and language-speaking) in a } \\
\text { work I've just learned. }\end{array}$ & ם & ם & ם & ם & ם \\
\hline $\begin{array}{l}\text { 20. Chorus director rehearses me by dividing parts of a large work into smaller pieces so that I can } \\
\text { understand easily. }\end{array}$ & ם & ם & ם & ם & ם \\
\hline $\begin{array}{l}\text { 21. Chorus director outlines everything so that I can improve my musical performance and makes } \\
\text { a detailed description of my performance. }\end{array}$ & ם & ם & a & ם & ם \\
\hline $\begin{array}{l}\text { 22. Chorus director commits to provide many new performance opportunities so that I can explore } \\
\text { new musical knowledge and skills. }\end{array}$ & ם & a & a & ם & ם \\
\hline $\begin{array}{l}\text { 23. Chorus director consistently sets targets for rehearsals by telling us that the chorus will give } \\
\text { concerts in and out of the university (concerts, festivals, choir competitions, workshops, } \\
\text { congresses, symposia, seminars, workshops, etc.). }\end{array}$ & ם & ם & ם & ם & ם \\
\hline $\begin{array}{l}\text { 24. Chorus director tells me to what extent I should work for the performance in the following } \\
\text { days. }\end{array}$ & ם & ם & ם & ם & ם \\
\hline $\begin{array}{l}\text { 25. Chorus director says what we learn during "choral music training" are very important in the } \\
\text { profession of teaching music. }\end{array}$ & ם & ם & ב & ם & ם \\
\hline $\begin{array}{l}\text { 26. Chorus director says "attendance to rehearsals and harmony in the chorus" are essential, in } \\
\text { addition to working hard during chorus lessons. }\end{array}$ & ם & ם & ב & ם & ם \\
\hline $\begin{array}{l}\text { 27. Chorus director gives me very little time to successfully complete rehearsals about my sound } \\
\text { area /partitur (soprano, alto, bass, tenor). }\end{array}$ & ם & ם & ב & ם & ם \\
\hline 28. Chorus director says s/he will punish the whole group for a mistake I made during rehearsals. & ם & ם & ם & ם & ם \\
\hline $\begin{array}{l}\text { 29. Chorus director uses derogatory expressions before my friends in order to punish me for a } \\
\text { mistake I made during rehearsals. }\end{array}$ & ם & 口 & ב & 口 & ם \\
\hline $\begin{array}{l}\text { 30. Chorus director says s/he is not satisfied by my efforts without providing me any specific } \\
\text { strategy for improving my ability to sing with a musical sensibility. }\end{array}$ & व & ם & ם & ם & ם \\
\hline
\end{tabular}

- Özgül, İlhan ve Yiğit, Nalân (2013). Chorus Motivation Scale (CMS).

Note. Due to the nature of the scale, "Does not affect my motivation" score ( 3 points) is a balance between decreases my motivation a lot (negative direction, 1 point) and increases my motivation a lot (positive direction, 5 points). Therefore, the interpretation of the scores from the scale should be made in the following way: As the score of any factor approaches 5 , this means the students are positively affected by that factor; as it approaches 1 , this means they are negatively affected by that factor, and as it approaches 3, this means they are not affected much by that factor. Chorus motivation scale items are written in the following order. Leadership (first 16), director/student attention (6), achievement (4) and anxiety (4).

\section{Copyrights}

Copyright for this article is retained by the author(s), with first publication rights granted to the journal.

This is an open-access article distributed under the terms and conditions of the Creative Commons Attribution license (http://creativecommons.org/licenses/by/4.0/). 